\title{
Aspects Regarding the Socio-Economic Indicators Used in Approaching the Territorial Disparities
}

\author{
Ancuța Cătălina ${ }^{A}$
}

Received: December 2011 | First Revised: January 2012 | Accepted: February 2012

\begin{abstract}
Territorial disparities are a common topic in the studies of geographers and of the institutions responsible for local, regional and national development, as well as in the political discourse. The large number of studies offers a great variety of methodologies. The article starts with defining the concept of disparities while specifying its paradigm, then proposes a synthesis of approaches towards the analysis of regional disparities, establishing several types of such approaches and provides an example of detailed analysis on an intra-regional level of a region of Romania - Banat.
\end{abstract}

Key words: disparities - definition and paradigm, socio-economic indicators, methodology, Banat [Romania]

\section{Introduction}

The attention for territorial disparities became systematic starting with years 50 (20 $0^{\text {th }}$ century) when the society realized the social and political risks that the disparities can determine.

Under the influence of regional science (W. Isard, cf. Benko, I998), disparities became a frequent topic for the studies of regional geography in the 2nd half of the $20^{\text {th }}$ century, on one hand because the existance of disparities had specific effects on the structure and functionality of territory and on the other because the inequality was considered a violation of ethical norms (Dramowicz, I985).

Territorial cohesion is an explicit objective of the Lisbon Agenda. The objective of the territorial cohesion is that of encouraging the harmonious and sustainable development of all the territories, based on their characteristics and resources (The Report by the European Commission to European Parliament, page I3).

The concept is considered important because it draws attention to the importance of taking into account territorial effects of different policies.

The lack of cohesion is emphasized by studying territorial disparities.
The concept of disparity and its paradigm Etymologically, the word comes from the Latin word disparilitas for which the RomanianLatin Dictionary (Guţu, Gh., I983, p. 356) records the meaning of dissimilarity, difference. Consequently, various dictionaries note that the notion of disparity names an "inequality, difference, lack of similarity, heterogeneity" (Le Petit Robert, I99I, p. 552, cf. Ancuţa, 20I0).

Numerous studies which present one aspect or another of the management or functioning of territorial ensembles assume as self-evident that the term indicates an inequality.

However, in the case of geographical studies, has to be done a supplementary specification, indicating that this term is not related to just any inequality, but to an inequality "felt, perceived and lived as an injustice" (Brunet, Ferras, Thery, I992, cf. Ancuţa, idem).

This inequality may correspond to a difference in different areas - social, economic, cultural, etc. but it is important to specify that we are dealing with disparities if the differences reach high values, having an impact on the functioning of the territorial system and on the development of the economy (George, I980, cf. Ancuţa, ibid).

\footnotetext{
A Department of Geography, West University of Timişoara, B-dul. V. Pârvan 4, 300223 Timişoara, Romania; e-mail: ancuta.catalina@cbg.uvt.ro
} 
The disparities are necessarily measured against an implicit reference default, emphasizing the degree of deviation from it.

Therefore, the difficulty lies precisely in choosing this reference default, which needs to be "correlated with the temporal and spatial context of that society" (Aydalot, cf. Ancuţa, 20o8).

Addressing territorial disparities is extremely nuanced: on one hand according to the chosen society and on the other according to several related concepts on which is built the discourse about disparities and which influence the way in which these are addressed.

These are: spatial justice, equity, equality, development, concepts which, in our opinion, have accompanied the approaches of the geographers in their attempt to make themselves useful to society, "social commitment being an important facet of the new geography" (Claval, I995).

Spatial justice is that form of social justice related to the relative compensation of inequalities of access to equipment and to other comparative advantages of places and, especially, related to the compensation of local differentiations of income.

Equality and equity are fundamental philosophical concepts that have fuelled a wide range of economic, political and social theories and debates. The manner in which these two concepts are interpreted by society influences the perception of spatial justice. Equality implies that all people are equal and should have equal statuses, equal wealth and equal influence.

Equity refers to equal subjection of all people to the same laws. Thus, justice in terms of equality is achieved when all people have the same quantities of everything, and in terms of equity, when all people operate under the same set of laws which are correctly applied.

In some societies, social justice is interpreted as a "free market competition between all members of the society, as they compete for rewards on an equal basis, depending on their skills and willingness to work". Other conceptions of social justice focus on a reward system granted "as per needs", for the greater common well-being, or granted depending on the degree to which a person or a region is suffering from natural, economic, cultural drawbacks.

The first interpretation is that of equity of opportunities, and second is that of equity of effects (Smith, I995).

The terms in which is defined the process of development influence the point of view through which disparities are analyzed, given that these are perceived first of all (as it will be shown below) a result of uneven development.

The two fundamental ways of understanding development are "Development = Economic Growth", respectively "Development = Modernization".
The equivalence between Development $=$ Economic Growth would translate into a concern for sustained and irreversible growth of the GDP, disparities between various spatial entities being analyzed as differences in productivity.

At the core of this conception lies the belief that economic rationality is the mechanism which regulates the entire social body and the relationships between the society and the physical environment.

The association between productivism and social evolution led to a reductive representation of the development by imposing a single model, a single purpose - the purpose of economic growth and by reducing the notion of "individual well-being" to use and storage of goods.

Development as Modernization is aimed at transforming traditional societies not only from an economic point of view, but also in their social, cultural, political aspects. Development as Modernization is capable of increasing the chances to life and well-being, and respects people's right to individual and group differences. It expresses "the process of expansion of opportunities through which present and future generations can fully manifest their options in every field: economic, social, cultural or political; man being placed at the centre of all action aimed at development" (Erdeli, Braghina, Frasineanu, 200o). It is therefore a concept which emphasizes that, besides the economic dimension, other dimensions like: the family and demographics related dimension, the political and cultural dimension and the social dimension are at least equally important. These four dimensions are highly interdependent, so that any change in any of these fields induces changes in the others.

Eco-development is a concept that has emerged alongside increasing environmental concerns, which are aimed at improving the quality of life and at protecting nature. Eco-development is a development of the populations through themselves, by making a better use of their natural resources, by adapting to an environment that they change without destroying it. The idea of eco-development points out the fact that environmental protection, social equity and economic growth are not only interdependent, but compatible and necessary most of all. The alliance between man and nature in a social project oriented towards the perspective of endogenous development, by respecting cultural diversity, and the coverage of basic needs: this is the ultimate objective of ecodevelopment. The individual and collective "wellbeing" does not suppose only the equalization of opportunities (understood mostly as an equal spatial distribution of job opportunities), but mainly the protection and conservation of nature. 
These are the new "scarce goods" of a refined urban society, for which the quantity is less important than the quality of life, the focus being put on improving the environment of life.

An evolution of the "patterns" of development can therefore be noted, whose defining elements were, consecutively, at the core of studies related to disparities.

The major change in the development-related issues makes the opposition between production and protection, between economic and cultural, as well as between the macro-spatial and microspatial conceptions to be considered unacceptable (Laccour, Puissant, I992).

The refinement of the concept of development considered to be responsible for disparities - took place while more and more involved elements were progressively identified and in parallel with the affirmation of the concept of territory, whose reality should have been better known, as upon which interventions should have been done (Navalpotro, 2000).

On the epistemological level, this process has facilitated the transition from spatial disparities to territorial disparities.

"The reference to the territory has appeared essentially as a political and anti-economic response to a totalitarian and excessive theorization of industrial and Productivist interventionism of the state, by recovering the strong arguments of regionalism" (Lacour, Puissant, idem, p. Io07).

„The systemic approach opposes reductionism ${ }^{\mathrm{I}}$, for binding the taking into account of complexity and retains all the relationships and elements. It is opposed to determinism: nature is not in command; there is a set of relationships. We can find engines, brakes, speed changers, etc.: but not a primary cause or a last resort. It avoids the excessive emphasis on the genesis, which is often just another way to return to singularity (exceptionalism - our note); it requires the definition of the present system, and of the remnants, bringing (geographers - our note) in a position to specify the histor-

1 Reference is made to the approaches from the point of view of the concept of "functional regions", corresponding to Functionalism as a paradigm of Geography, as well as to Structuralism, the general paradigm of science in the neo-industrial stage (...) (Vallega); the central concern was that of revealing the structure of the functional region, consisting of a central area and a gravity area. It is accused of reductionism because of two reasons: the incomplete way in which it understood the structure of functions (only partially studied: the tertiary ones, considered important for the urban and the industrial ones, important for the metropolitan areas) and the ignoring of the relationship between human communities and nature, with focus on relationships in the horizontal plan, as explaining the distribution of functions in the territory. ical relativity, the changing as well as the processes, the laws, the models that act" (Brunet, 200I).

The takeover by the geography of the general systems theory is "a fascinating and challenging way to an understanding of the unity of nature, science and society" (Haigh, I985, according to Nir, I990, p 75).

In contrast, therefore, to structuralism, which required the division of the object investigated into its elementary structure - an approach which leads to the "atomization of science" (Nir, idem, p. 75) -, the systemic approach places the whole foreground.

After dedicating itself to the humanized region (and lifestyles) in the first half of the twentieth century, then to the polarized region in the second half of the same century, human regional geography, recovers the system, as the most appropriate reading grid to interpret the so complex reality named the territory, respectively the territorial system.

A system is a set of interacting elements and the relationships between them; elements become components of the system due to the relationships between them, the state of each component being constrained, conditioned and dependent on the states of the other ones (Bertalanffy, I97I, according to Nir, I990, p. 77).

It follows from here that if approached in terms of system, the territory has three defining aspects: the components, the processes and the structure.

The theoretical approaches of the territorial system (Dauphiné, I979, Cunha, I988, Brunet and Dolfus, I990, Nir, I990, lanos, 2000, Haggett, 200I) provide exhaustive images of this reading grid.

The complex territorial system includes physical-geographical but also social and economic components and it is necessary to identify the processes that condition the intensity and quality of their interactions.

The ones that represent "the energy of the system" are highlighted as essential: labour, environment resources, information, capital, means of production, control centres, and the relationships between them within the "regulator block" are pointed out.

The flows - of matter, energy, information - reflect the functioning of the system. Structure elements (the way in which the physical components are arranged, including the inherited ones, related to "territorial inertia") are represented by: network layouts, roads, equipments, settlements, distances, locations, relative positions.

The superstructure - including values, culture, way of thinking and acting, preferences, way of living - determines the behaviour of actors, respectively defines their objective and thus the direction of evolution of the territorial system (factors of satisfaction, joy of living, unmet needs). 
The territorial system is an open system, where the inflows and outflows need to be defined in relation to the external environment. Retroactive (feedback) reactions occur in response to changes induced from outside and, if positive, these would determine a change in the function and structure of the system.

Approached as a system, the territory is conceived in terms of interaction, one being able to identify: the specific functions and hierarchy of several categories of actors, and of the components; the linkages between spatial structures and socio-economic processes which explain them; the state of the territory - of self-reproduction (the autopoïetic state ) or, conversely, of change.

The evaluation of territorial disparities has to start from the differenciation between: elementary disparities, defined as spatial diferenciation of the components, structure or process of the territorial system and teritorial (global) disparities, which mark the differences of the performance of the subsystems of the territorial system (Ancuţa, 2008).

Within the territory regarded as a system, the quantification of the differences in performance ${ }^{2}$ of subsystems and their comparison to the average performance of the territorial system means highlighting the territorial disparities.

Against such a synthetic approach, the assessment/ quantification of the quality of components on the level of subsystems and their comparison to the norm represented by the average values on the level of the territorial system allows to reveal the elementary/functional disparities. Therefore, the elementary disparities are defined as spatial diferenciation of the components, structure or process of the territorial system.

The analysis of the latter ones, in order to be heuristic, needs to be done from the perspective of the whole territorial system.

Thus, elementary disparities may indicate structure and inter-conditioning elements that may be useful in studying territorial disparities.

Once the territorial disparities revealed, the approach must focus on two directions: revealing their conditions of apparition and, respectively, their effects.

\section{Socio-economic indicators and methods used for studying disparities}

In the context of the evolution of the epistemological field outlined above, studies on territorial disparities have varied their methodology.

Thus, it can be emphasized that the choice of indicators was done in relation with the conno-

2 This is a concept whose understanding evolves in connection with the paradigm of development, with direct influence on the assessment methodology. tation gave by different authors to the concepts of territory, development and also in relation with the objectives of the different studies.

The synthesis of the research approaches on disparities allowed us to establish several types that we have synthesized below (Tables I-3 and 5, Figures I-2).

Documents conceived at European level in order to underpin the policy of territorial cohesion aim to reveal the disparities, both the elementary and the territorial ones.

The European Commission Reports on economic and social cohesion $2002-2009$ comprise a lot of indicators, reflecting mainly the productivity (GDP), the employment, the education, the poverty. Nevertheless, there is a need for indicators in order to reflect: accessibility, mobility, equipment,

Table 1. Structural and systemic perspective - descriptive and explanatory approach [cf. Cuhna, 1988; Ayydalot, 1985; Cocean, 2002]

\begin{tabular}{|l|l|l|}
\hline $\begin{array}{l}\text { Subsystems of the } \\
\text { territory }\end{array}$ & Concepts & Indicators \\
\hline demo-social & $\begin{array}{l}\text { anthropic pressure } \\
\text { living standard }\end{array}$ & $\begin{array}{l}\text { population density } \\
\text { demographic structure } \\
\text { income per capita, } \\
\text { characteristics of } \\
\text { residential areas } \\
\text { unemployment rate }\end{array}$ \\
\hline economic system & $\begin{array}{l}\text { endogenous } \\
\text { potential } \\
\text { qualified labor force }\end{array}$ & $\begin{array}{l}\text { job number } \\
\text { specialization } \\
\text { number of companies } \\
\text { headquarters } \\
\text { added value }\end{array}$ \\
\hline spatial & $\begin{array}{l}\text { poles } \\
\text { peripheries }\end{array}$ & $\begin{array}{l}\text { centrality } \\
\text { dispersion }\end{array}$ \\
\hline nature & $\begin{array}{l}\text { environmental } \\
\text { quality }\end{array}$ & environmental indicators \\
\hline
\end{tabular}

Table 2. Analysis of regional models [cf. Cocossis, Psycharis, 2008]

\begin{tabular}{|l|l|}
\hline Territorial components & Indicators \\
\hline labor force & $\begin{array}{l}\text { illiteracy, } \\
\text { the proportion of the employment in the } \\
\text { tertiary sector, } \\
\text { the proportion of the employment in the } \\
\text { secondary sector, the proportion of jobs } \\
\text { requiring qualification, } \\
\text { the proportion of those who do not } \\
\text { require skilled labor; }\end{array}$ \\
\hline labor market & $\begin{array}{l}\text { employment rate, } \\
\text { unemployment rate, } \\
\text { unemployment rate among young } \\
\text { people, } \\
\text { inactive population rate }\end{array}$ \\
\hline regional economic & $\begin{array}{l}\text { GDP/capita, } \\
\text { revenue/capita, } \\
\text { productivity, } \\
\text { economic growth rate }\end{array}$ \\
\hline regional structure & $\begin{array}{l}\text { degree of urbanization, } \\
\text { specialization }\end{array}$ \\
\hline
\end{tabular}


Table 3. Analysis of regional audit [cf. Stimson et al., 2006]

\begin{tabular}{|c|c|}
\hline Main territorial structures & Territorial components \\
\hline $\begin{array}{l}\text { socio-economic } \\
\text { envronment }\end{array}$ & $\begin{array}{l}\text { demography, labor market, } \\
\text { economic system [GDP, exchange data, } \\
\text { capital], community services, } \\
\text { location, } \\
\text { resources, } \\
\text { competitive advantages, } \\
\text { infrastructure [type, capacity, quality, } \\
\text { flexibility], } \\
\text { technology [type, level, intensity of use } \\
\text { of new technologies in the process of } \\
\text { production]. }\end{array}$ \\
\hline institutional environment & $\begin{array}{l}\text { political institutions, } \\
\text { economic/commercial organizations, } \\
\text { financial institutions, } \\
\text { community development projects, } \\
\text { social development programs, } \\
\text { education and training. }\end{array}$ \\
\hline
\end{tabular}

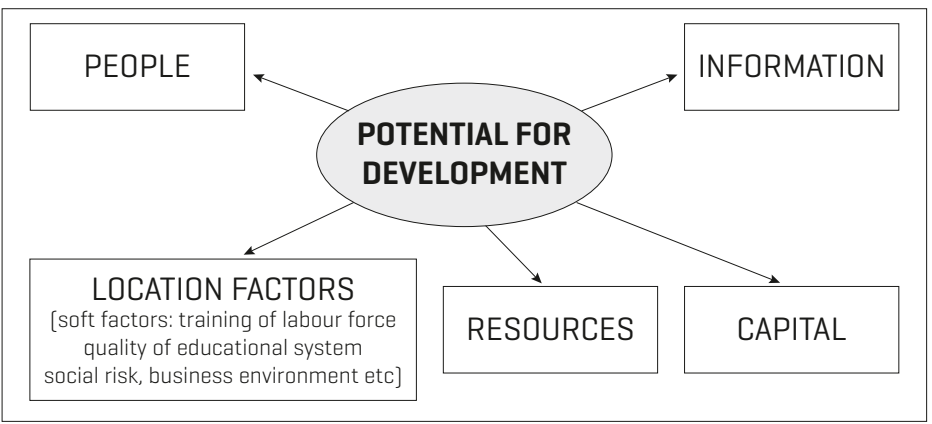

Figure 1. Elements taken into consideration in a prospective approach [cf. Brunet, 2001, Glasson, Marshall, 2007, Mosse, Farington, Rew, 2006]

Table 4. Analysis performed in terms of territorial dyagnosis [cf. Stimson et al., 2006]

\begin{tabular}{|l|l|}
\hline Domains of intervention & Analyzed elements \\
\hline settlements development & $\begin{array}{l}\text { natural resources, assessment of } \\
\text { growth poles, community services }\end{array}$ \\
\hline business development & $\begin{array}{l}\text { material flow and production } \\
\text { accounting, cost/benefit }\end{array}$ \\
\hline $\begin{array}{l}\text { human resources } \\
\text { development policies }\end{array}$ & $\begin{array}{l}\text { existing qualification compared to } \\
\text { necessary qualification, comparative } \\
\text { analysis of sector growth rates at local/ } \\
\text { national level [shift and share analysis], }\end{array}$ \\
\hline $\begin{array}{l}\text { capitalization of local } \\
\text { resources }\end{array}$ & $\begin{array}{l}\text { community networks, costs/benefits of } \\
\text { the community }\end{array}$ \\
\hline
\end{tabular}

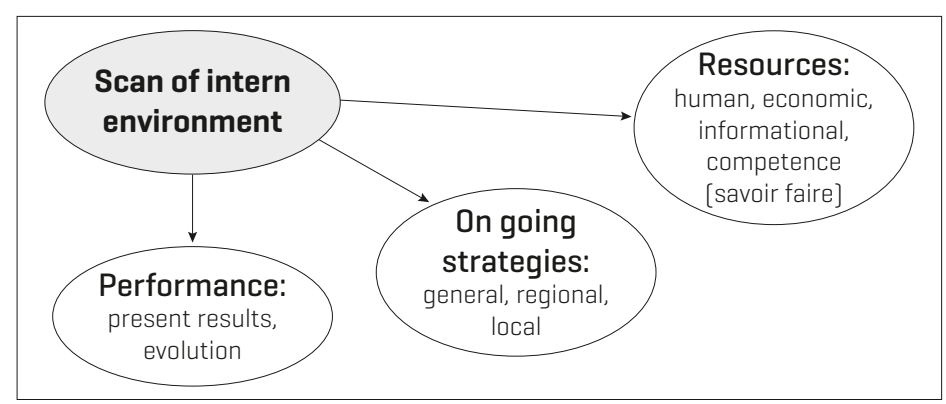

Figure 2. Analysis from strategic planning perspective [cf. Glasson, Marshall, 2007] services, demography, labor market, risks, governance, and integration.

The urban audit covers 300 variables plus derivative indicators related to 9 fields of urban life: demography, economy and society, education, civic implication, mobility and environment.

The methodology used for studying disparities implies:

- a statistical analysis of indicators values, usually based on the average (which, in term of studying disparities, is the norm), the standard deviation, the min-max ratio, the distribution by quartiles (Ancuţa, 2008);

- for dynamic approaches (which take into consideration an interval, not only one moment), the methodology implies the revealing of convergence trends, respectively, divergence trends (Geppert, Stephan, 2008);

- mathematical taxonomy (hierarchical ascending classification) is used in order to establish some spatial types, according to the distance from the regional norm (Muntele, Groza, Ţurcănaşu, 2002);

- mapping translation highlights spatial typologies or spatial hierarchies (Coccossis, Psycharis, 2008; Stimson et al., 2006).

\section{Study case: evaluation of territorial disparites in Romania Banat}

The Banat is the region in south-western Romania (Figure 3), which still presents a global level of development superior to other Romanian regions but which, on an intra-regional level, has been affected differently by the process of economic transition.

The study of disparities seeks therefore to reveal intra-regional disparities and to allow the highlighting of the regional model.

Starting with the multidimensional nature of the concept of development and with the territory viewed as a system, against the statistic database offered by the national institutions, the following indicators were selected:

- in order to evaluate the state of the economy: turnover/capita (AFA), unemployment (SOM), percent of employees in the active population (SAL), physiological density (inhabitants/agricultural land in hectares);

- in order to evaluate the social and demographic situation: the intensity of depopulation (DEP), calculated as ratio of people registered in two consecutive censuses; the percent of population working in agriculture in the total active population (AGR); percent of old population in the total population (over 60 years of age/total population) (BAT); percent of high school graduates in the over I2 years of age population (LIC); 
- in order to emphasize the differentiations in life standard: the inhabitable area ( $\mathrm{m}^{2} /$ person) (SUP) and the number of telephones at rooo persons (TEL).

First, elementary disparities (as defined above) were analyzed.

The algorithm applied in analyzing the elementary disparities was as follows: statistical analysis and cartographic analysis.

\section{Statistical and descriptive analysis}

The analysis of dispersion was done, with the purpose of determining the "weight" of elementary variables in the emerging of global disparities.

In this respect, was analyzed the specific weight of the characteristic intervals - the first and last deciles, respectively the first and last quartiles -; higher specific weights suggest, of course, a large dispersion and therefore an important contribution of the respective variable to intra-regional disparities.

The variables were analyzed using data from the last two censuses, in order to highlight the evolution trends in elementary disparities, induced by each variable.

Also, in order to highlight the role that plays each variable in the increase or decrease of interregional disparities, we chose to calculate and analyze the coefficient of variation (simple indicator of dispersion).

Unlike other indicators of dispersion, this indicator allows the comparison of "the dispersions of different distributions by variables expressed in different measure units"3.

It is calculated as the percentage ratio between the standard deviation and the arithmetic mean: the more it tends to $o$, the more the statistical population is homogeneous, the more it tends to Ioo, the dispersion is more intense and the statistical population is more heterogeneous.

The convergence, respectively the divergence of the values of this indicator calculated for the two consecutive censuses signifies the decrease, respectively the increase of the role of a particular variable in the global disparities at a regional level.

\section{The cartographic analysis}

It highlights the gain of taking into account of the spatial dimension in the study of regional disparities.

In this respect, the cartograms are the ones that offer the opportunity of identifying the areas where a certain component of the territorial system, or a particular feature of it constitutes an asset or a problem, and so a possible domain of intervention.

\footnotetext{
3 Jaba, I998, p. I49.
}

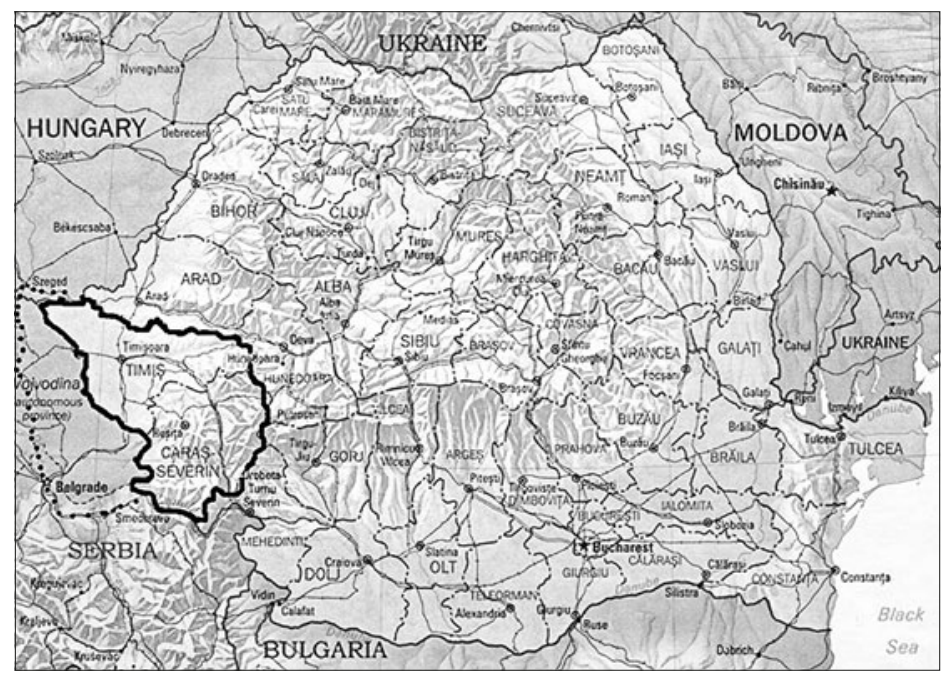

Figure 3. Geographical positions of Romanian Banat and historical Banat

[source: http://nationmaster.com/images/motw/europe/romania.gif, modified]

The heuristic analysis (the genetic-explanatory type) of the values situated below the regional average within some areas, respectively of those situated above regional average in other areas, provides useful elements for defining interventions within development strategies.

Choosing the variation intervals should not lead to an excessive fragmentation of the statistical population and has to include an interval of the regional average (the value of the arithmetic mean should not constitute limit of interval).

We shall exemplify this approach by presenting the analysis of one of the socio-economic variables considered in the larger study mentioned above (Ancuţa, 2008, 20Io) the unemployment rate (the share of unemployed population within the active population) in the years 1992 and respectively 2002 .

Unemployment rate (SOM) and its intra-regional variations is a suggestive measure of social equilibrium, because the integration of active population in economic activities is an initial condition of its prosperity.

For the year 1992 the values present a great dispersion (Figure 4). Spatially, the regional pole and its immediate area stand out, having values corresponding to the regional average interval.

In the north-western part of the region, small towns and their polarization areas have values situated above the average due to the social effects of restructuration process suffered by their industry immediately after I989. The south-eastern part, for which state support continued until I997-I998, is below the regional average (Figure 5).

In 2002, the unemployment rate has even bigger intra-regional disparities (Figure 6). This time, the situation is favourable in the north-west (where the benefits from the transition to market 


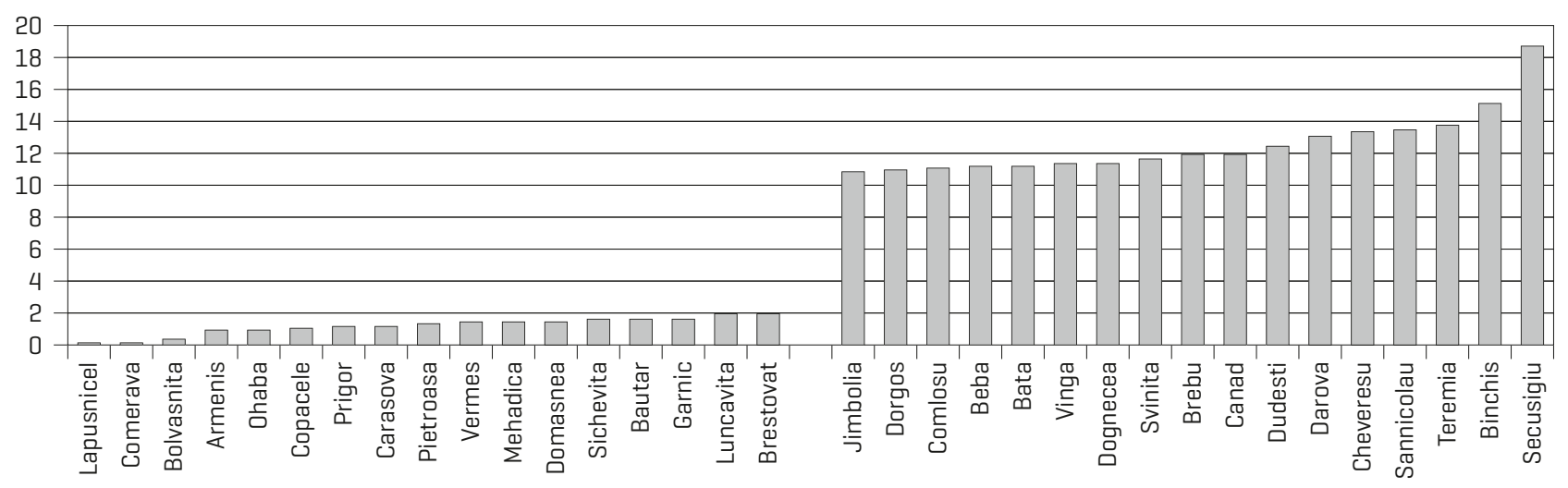

Figure 4. Values of SOM variable for the unities of the $1^{\text {st }}$ and respectively of the $10^{\text {th }}$ deciles [1992] [cf. Ancuța, 2008]

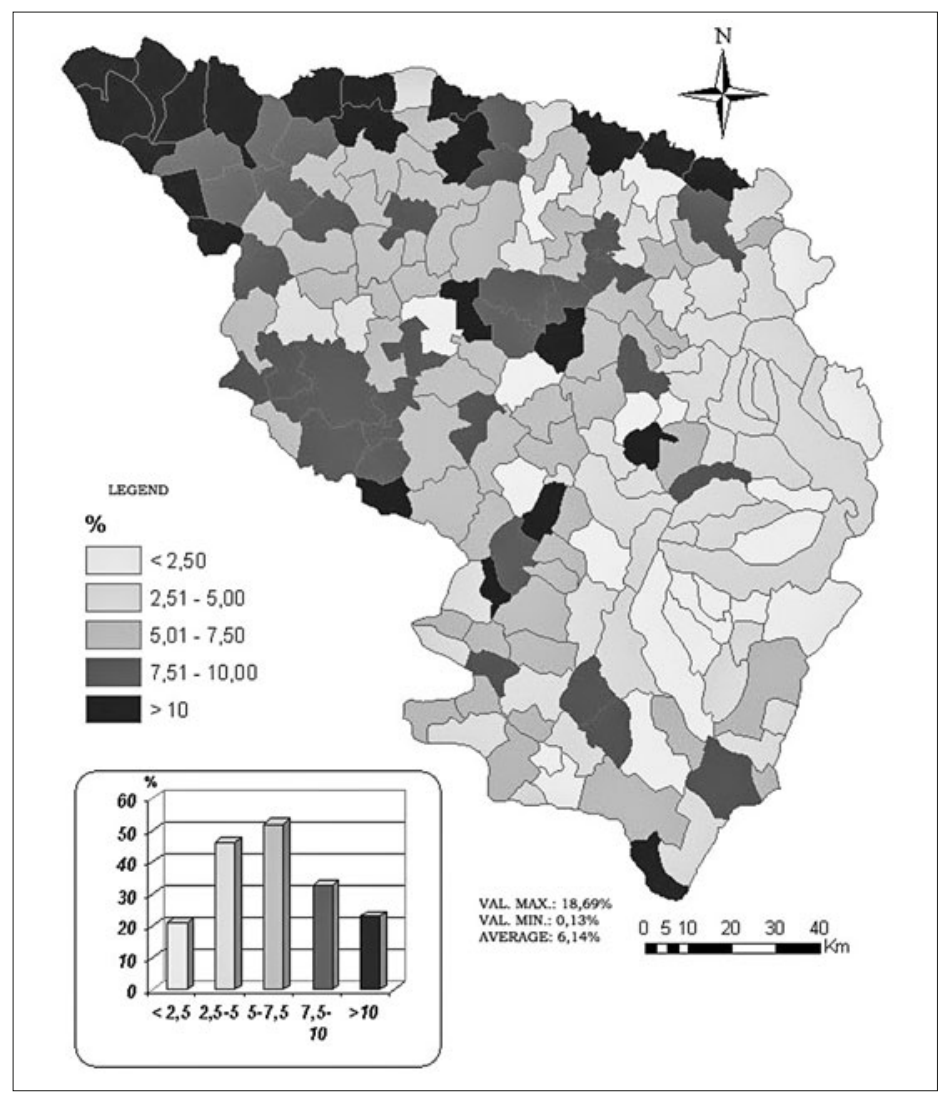

Figure 5. Unemployment rate [SOM] -1992 [cf. Ancuța, 2010] economy started in the early I990s have already appeared) and critical in the south-east (where, after the stop of the state subsidies in 1997 - I998, a real collapse of the economy happened) (Figure 7).

The values of the averages of the characteristic intervals in 2002, compared with 1992 emphasize the accentuation of the dispersion of the statistical population and, thus, of the divergence at intraregional level (Table 5).

The variation coefficient (defined above) of variable SOM grows from $53,25 \%$ - in 1992 - to $85,95 \%$ - in 2002 - which suggests once again the accentuation of the role of this variable in determining intraregional disparities.

The global disparities (as defined above) were highlighted using a complex development index, calculated as it follows:

INDEZV=50+I4(AFA+SUP+LIC+TEL+DEF+S AL-DEP-AGR-BAT-SOM)/ıo (Ianoş, I997).

The mapping of the values of this indicator has led to the establishing of two categories of areas, in relation with the average level of regional development: advantaged areas, with INDEZV superior to the regional average and disadvantaged areas, with INDEZV inferior to the regional average.

The SWOT analysis of these areas, together with the study of their behaviour in the interval 19922002, made possible the establishing of spatial ti-

Table 5. The distance between the characteristic intervals of the variable SOM and the tendency of evolution in the 1992-2002 decade

\begin{tabular}{|l|l|l|l|l|}
\hline $\begin{array}{l}\text { The characteristic } \\
\text { intervals }\end{array}$ & $\begin{array}{l}\text { The average of the } \\
\text { characteristic intervals } \\
\text { in 1992 }\end{array}$ & $\begin{array}{l}\text { \% from the regional } \\
\text { average [regional } \\
\text { average 1992=100\%] }\end{array}$ & $\begin{array}{l}\text { The average of the } \\
\text { characteristic intervals } \\
\text { in 2002 }\end{array}$ & $\begin{array}{l}\text { \% from the regional } \\
\text { average [regional } \\
\text { average 2002=100\%] }\end{array}$ \\
\hline 1 st decile & $1,2 \%$ & $19,54 \%$ & $1,37 \%$ & $13,74 \%$ \\
\hline 10 th decile & $12,51 \%$ & $203,74 \%$ & $29,76 \%$ & $298,49 \%$ \\
\hline 1 st quartile & $2,25 \%$ & $36,64 \%$ & $2,37 \%$ & $23,77 \%$ \\
\hline 4 th quartile & $10,58 \%$ & $172,31 \%$ & $22,30 \%$ & $223,67 \%$ \\
\hline
\end{tabular}

[Data source: calculated data] 


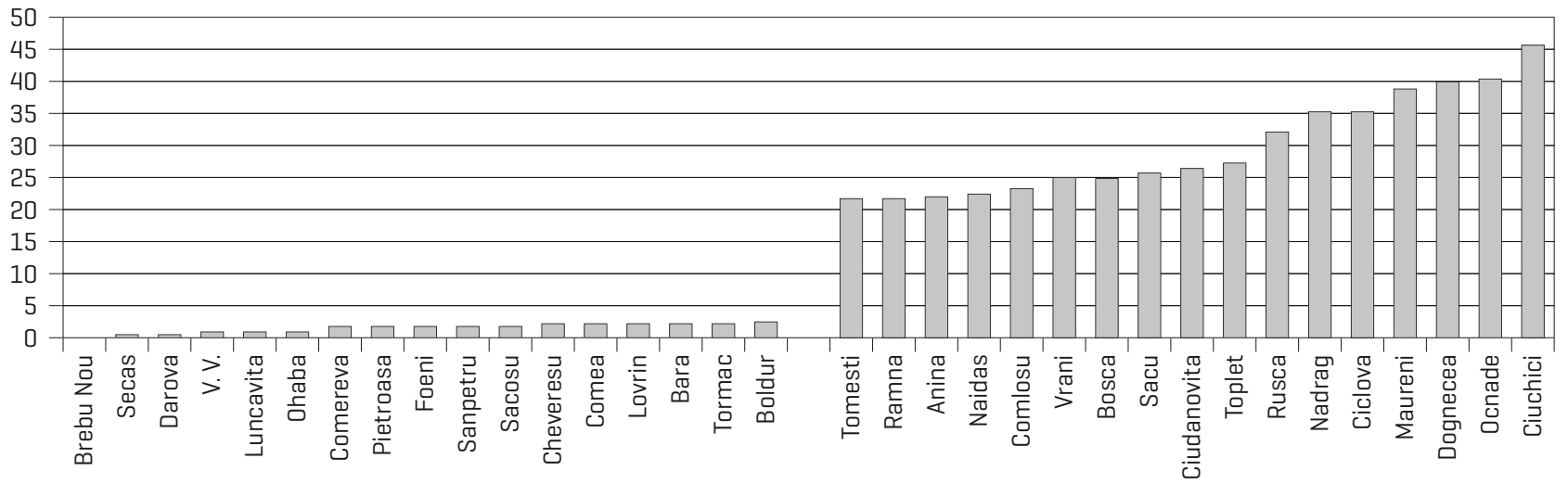

Figure 6. Values of SOM variable for the unities of the $1^{\text {st }}$ and respectively of the $10^{\text {th }}$ deciles [2002] [cf. Ancuța, 2008]

pology and of the territorial model of the region, which includes: an urban effervescent area, an urban area in crisis, an affirmation area and several types of rurat areas - profound rural areas, integrated rural areas, agricultural area (Ancuţa, 2008).

\section{Conclusions}

The study of territorial disparities has evolved along with its own paradigm, as well as along with the supply of statistical data and with social command.

Based on the studies of territorial disparities can be differentiated several types of approaches: structural and systemic perspective; descriptive and explanatory approach; analysis of regional models; analysis of regional audit; prospective approach; analysis performed in terms of territorial diagnosis; analysis from strategic planning perspective.

Studies should not necessarily be exhaustive, but should take into account the multidimensional nature of the two basic concepts of the paradigm of disparities - the concept of development, as well as that of territory.

Also, starting from the relational character of information in a territorial system (Ianoş, 2000), researchers can choose those variables that they consider to be significant for more components and processes within the territory.

The evaluation of territorial disparities has to start from the differenciation between: elementary disparities, defined as spatial diferenciation of the components, structure or process of the territorial system and teritorial (global) disparities, which mark the differences of the performance of the subsystems of the territorial system (Ancuţa, 2008).

The methodology involves the use of statistical and descriptive analysis and mapping methods, sometimes supplemented by classifications, taxonomies territorial, SWOT analysis and spatial modelling.

Given the character of applied research of studies concerning territorial disparities, the

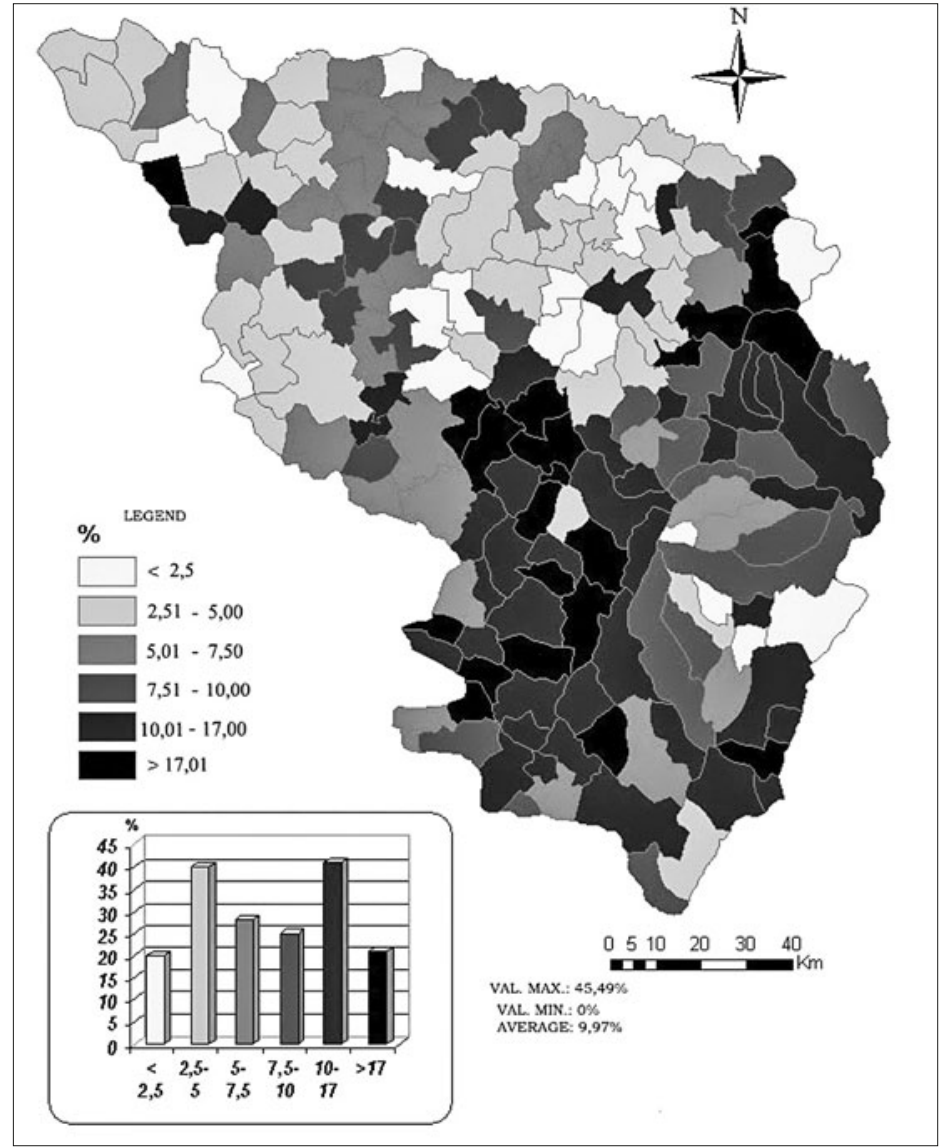

Figure 7. Unemployment rate [SOM] - 2002 [cf. Ancuța, 2010]

communication of research results is an important aspect.

From this perspective, the use of indicators that are relevant and easy to explain to potential beneficiaries of research results, and of suggestive graphics is recommended.

This way, the local authorities, the local or government people in charge, as well as the inhabitants of the different types of areas identified, will be helped along to realize the development related issues and therefore will be easier persuaded to congregate around the objectives of the needed future development strategies. 


\section{Acknowledgements}

This contribution presents some results from the research projects ID IO74 (VESTPROSPECT) and ID IO67, financed by CNCSIS (National Council of Scientific Research from Higher Education), in the frame of National Plan II, ID programme and also POSDRU/89/I.5/S/63663 "Trans-national network of integrated management for post-doctoral research in the field of Science Communication. Institutional construction (post-doctoral school) and fellowship Programme (CommScie)". The author acknowledges to anonymous reviewers for their thoughtful suggestions and comments.

\section{References}

Ancuta, C. 2008. The Geographical Study of Territorial Disparities in Romanian Banat. Mirton Publishing House, Timişoara, 275 pp. (in Romanian)

Ancuţa, C. 2010. Territorial Disparities in the Romanian Banat: Assessment, Dynamics and Impact on the Territorial System. Journal of Urban and Regional Analysis (JURA) 2, 45-62.

Aydalot, P. I985. Regional and urban economy. Economica Publishing House, Paris, pp. 487. (in French)

Benko, G. I998. The Regional Science. PUF, Paris, I26 pp. (in French)

Brunet, R., Dolfus, O. I990. Universal Geography. New Worlds. Ed. Hachette/Reclus, Paris, pp. 550. (in French)

Brunet, R. 20or. The Decryption of the World. Belin, Paris, pp. 394. (in French)

Coccossis, H., Psycharis, Y. 2008. Regional Analysis and Policy. The Greek Experience. PhysicaVerlag, Heidelberg, 393 pp.

Claval, P. 1995. The Cultural Geographie. Nathan, Paris, 384 pp. (in French)

Cocean, P. 2002. Regional Geography. Presa Universitară Clujeană, Cluj Napoca, pp. 157. (in Romanian)

Cuhna, A. 1988. Systems and Territory: Values, Concepts and Indicators for Another Developpment. L'Espace geographique, 5, I8I- I98. (in French)

Dauphiné, A. 1979. Space, Region, System. Ed. Economica, Paris, pp. 167. (in French)

Dramowicz, K. I985. Some problems of disparities in Poland 's regional development. Geographia Polonica 5I, 313-321.

Erdeli, G., Braghină, C., Frăsineanu, D. 200o. Global Economic Geography. Foundation "România de mâine" Publishing House, Bucureşti, 268-267.

Felenstein, D., Portnov, B.A. (eds) 2005. Regional Disparities in Small Countries. Springer, Berlin, Heidelberg, New York, 333 p.

Geppert, K., Stephan, A., 2008. Regional Disparities in the European Union: Convergence and
Agglomeration. Papers in Regional Science 2, 193217 .

Glasson, J., Marshall, T. 2007. Regional Planning. Routledge, London, Paris, 316 pp.

Guţu, Gh. 1983. Dictionary Latin-Romanian, Editura Enciclopedică, Bucureşti.

Haggett, P. 200I. Geography, a global synthesis. Prentice Hall, Horlow-London-New York, pp. 833.

lanoş, I. 200o. Territorial Systems. A Geographical Approach. Editura Tehnică, Bucureşti, pp. I98. (in Romanian)

Jaba, E. 1998. Statistics. Editura Economică, Bucureşti, pp. 464. (in Romanian)

Lacour, C., Puissant, S. 1992. Applied Geography and Science of Territories. Encyclopedie de Géographie. Economica, Paris, I003-IO22. (in French)

Mosse, D., Farrington, J., Rew, A. 2006. Development as Process. Routledge, London, New York, 202 pp.

Muntele, I., Groza, O., Ţurcănaşu, G. 2002. The Regionalization of Rural Spaces From Moldavia in the Transition Period. The Geographical Base for Development Strategies. Ungureanu, A., Groza, O., Muntele, I. (eds) Moldavia: Population, Work Labor and human settlements in Transition. Corson Publishing House, laşi, I48I90. (in Romanian)

Navalpotro, J. A. 2000. Regional Development Models. Oxford University Press, Oxford,I6-I5I.

Nir, D. I990. Region as a Socio-Environmental System. An Intropuction to a Systemic Regional Geography. Kluwer Academic Publisher, Dordrecht/Boston/London, pp. 182.

Smith, D., M., I995. Back to the good life: towards an enlarge conception of social justice. Environment and planning D: Society and space I5, I9-35.

Stimson, R., Stough, R., Roberts, B. 2006. Regional Economic Development. Springer, Berlin, Heidelberg, pp. 53-I9I

**** Territorial cohesion: unleashing the territorial potential, Kiruna, IO-II december, 2009, 22 pag.

http://ec.europa.eu/regional_policy/consultation/terco/kiruna_2009I2II.pdf

http://www.espon.eu

http://www.urbanaudit.org/

http://www.gmes-gseland.info/com/promo/UrbanAtlas_Septo8.pdf

http://ec.europa.eu/regional_policy/newsroom/ pdf/pawel_samecki_orientation_paper.pdf

http://ec.europa.eu/regional_policy/sources/docgener/presenta/audit2009/audit2009_en.pdf

http://ec.europa.eu/regional_policy/sources/docgener/work/2009_oI_impact.pdf

http://ec.europa.eu/regional_policy/conferences/ od2009/university.cfm?nmenu=7000

http://www.regional-studies-assoc.ac.uk/events/ future.asp\#

http://ec.europa.eu/regional_policy/sources/docoffic/official/repor_en.htm 